\title{
Effectiveness of Structured Teaching Program on knowledge and practice of Nurses Regarding Prevention of Cervical Cancer in National Ribat Teaching Hospital, Khartoum State, Sudan (2016-2017)
}

\section{Amal Mohammed Hamid ${ }^{1 *}$ and Ahmed Mohammed Ahmed Fadalla ${ }^{2}$}

${ }^{1} \mathrm{PhD}$ candidate, senior lecturer obstetrics and gynecology nursing \&midwifery, Alzaiem Alazhari University, Khartoum, Sudan.

${ }^{2}$ Associated Professors, obstetrics and gynecology, Alzaiem Alazhari University, Sudan.
"Correspondence:

Amal Mohammed hamid, $\mathrm{PhD}$ candidate, senior lecturer obstetrics and gynecology nursing \& Midwifery, Alzaiem Alazhari University, Khartoum, Sudan, E-mail: omalbaneen470@yahoo.com.

Received: 04 December 2018; Accepted: 27 December 2018

Citation: Amal Mohammed hamid, Ahmed Mohammed Ahmed Fadalla. Effectiveness of Structured Teaching Program on knowledge and practice of Nurses Regarding Prevention of Cervical Cancer in National Ribat Teaching Hospital, Khartoum State, Sudan (20162017). Nur Primary Care. 2018; 2(5): 1-5.

\begin{abstract}
Background: Cancer of the uterine cervix is the second big cause of female mortality worldwide about 510.000 cases of cervical cancer are reported each year with nearly $80 \%$ in developing countries. Cervical cancer account for about $16.2 \%$ of all cancers among Sudanese women and is the second cause of death after breast cancers. A large number about $78 \%$ of women present with stage III or IV. Nurses as primary source of health education for their patients and public, can play a critical role in cervical cancer prevention and management, high awareness in methods of cervical cancer prevention among nurses is of a vital importance.
\end{abstract}

Aim of study: To evaluate the effectiveness of structured teaching program on knowledge and practice of nurses regarding prevention of cervical cancer and role of nurse in prevention.

Material and methods: The research design was quasi experimental study conducted in National Ribat teaching hospital at the gynecology department in Khartoum state from (2016-2017). The total coverage method used to lay down the sample which it was (50) staff nurses Data was collected by using a questionnaire (to measure the knowledge) and checklist (to measure the practice) and was analyzed by using Statistical Packages for Social Sciences (SPSS version 20).

Results: The study showed significant differences $(P<0.05)$ found in knowledge of staff nurses between the pre and post structured teaching program About (58\%) of staff nurses displayed correct answers regarding the risk factors of cervical cancer before attending the program, while after the program(82\%) of them displayed it correctly. Regarding the Pap smear test definition and cervical screening methods (46\%) of staff nurses gave correct answers before attending the program in contrast after the program (94\%) of them gave correct answers. (44\%) of the staff nurses answered correctly about the role of nurses in prevention of cervical cancer by health education before attending the program, while (88\%) of them answered correctly after attending the program. Also the study showed significant differences found $(P<0.05)$ in practical skills of staff nurses between pre and post structured teaching program, Most of staff nurses (80\%) after program demonstrated correct practices related to preparation and assisted in Pap smear procedure. Before the program (54\%) of staff nurses performed counseling in system to be followed in doing Pap smear correctly but after program most of them (90\%) performed it in right way.

Conclusion: The study concluded that structured teaching program had a significant impact related to the improvement of the staff nurses knowledge and practical skills post application of the program.

Recommendation: The study recommended that encourage training and continuous professional educational programs to staff nurses and to update nurses knowledge and practice in prevention of cervical cancer. 
Keywords

Structured Teaching Program, knowledge, Practice, Nurses, Prevention, Cervical Cancer.

\section{Introduction}

Every year cervical cancer kills 250.000 women and $58 \%$ of these deaths occur in low and middle income countries. Cervical cancer is fourth most frequent cancer in women worldwide but most of these deaths could be prevented with adequate prevention measures ,such as vaccination of girls against human papillomavirus (HPV) and screening programs to detect and treat precancerous lesions [1].

In Sudan cervical cancer account for about $16.2 \%$ of all cancers in Sudanese women, cervical cancer is the second common cancer in female $12-15.5 \%$ after breast cancer $29-34.5 \%, 78 \%$ of cases present with stage 111 and $1 \mathrm{~V}$,mostly postmenopausal females with more than three months history ,too shy to complain about vaginal bleeding and discharge [2]. Many factors contributed in advanced of Cervical Cancer in Sudan, which were lack of awareness of cervical smear and vaccination, lack of health education and early detection ,poverty ,illiteracy, the large size of the country ,local healers, the poor distribution of limited medical resources and lack of knowledge about cervical cancer and it is prevention measures among some health professionals which their key role in cervical cancer prevention and control is to identify women for whom cervical screening is recommended (age, sexual history ..ect), educating women about importance of regular Pap smear tests and informing women of the need to seek medical attention for abnormal vaginal bleeding and other clinical symptoms regardless of a normal Pap smear [3]. Cervical cancer is the preventable particularly if women are screened for precancerous cervical changes [4]. Fortunately, the incidence of cervical cancer has decreased by more than $50 \%$ in past 30 years, largely due to increasing use of cervical cancer screening with cervical cytology [5]. But even today millions of women in the developing countries are never screened for cervical cancer in their entire lifetime. Routine cytological screening should be offered to all Screening combined with vaccination can substantially reduce the worldwide cervical cancer mortality. Effective implementation of sustainable cervical cancer screening program using sufficiently sensitive and specific tests that covers minimum $70 \%$ of the targeted population through screening atleast once in a lifetime along with effective treatment is vital in reducing the burden of cervix cancers [6].

In health care field, nurses play many roles, a prominent one being a patient educator. As result there is a need to educate nurses about the risks and impact of HPV and cervical cancer prevention, increase their knowledge and improve their practice regarding prevention methods in cervical cancer can help in reducing the burden of cervical cancer among females. Nurses can be instrument in educating the public about cervical cancer and increasing awareness of HPV and prevention of cervical cancer among the women this is because they are more frequently in contact with women and their relations than other health care professionals [7]. Also nurses may be in contact with groups of families for many aspects of their health care, including maternal and child health care as well nurses take the majority of smears in orders to detect cancer of cervix at an early stage. It is important that the nurse provide women with sound and up-to-date information in way that they understand [8].

The aim of this study is to assess the effectiveness of structured teaching program on knowledge and practice of nurses regarding prevention of cervical cancer and role of nurse in prevention in gynecology department at National Ribat teaching hospital.

\section{Material and Methods}

Study design: Quasi experimental design one group pre-posttest. Study Setting:The study was conducted ingynecology department in National Ribat teaching hospital, Khartoum State, Sudan.

Study population: The population of the study included all staff nurses worked in study area during the study period and they agreed to participate in the study.

Sampling \&Sample size: Total coverage sample, their number was (50) due to limited and shortage of staff.

Data collection techniques and tools: Two tools used to collect the needed data to achieve the aim of the study, they were: Structured Interview questionnaire to assess the nurses knowledge regarding prevention of cervical cancer and role of nurse in prevention and observational Checklist to assess the nurses 'practice regarding prevention of cervical cancer. These tools developed by researcher after reviewing by experts in the field.

\section{Phases of the study}

Pre Intervention Phase: Baseline survey was conducted (pretest).

Intervention Phase: Started from (January - April 2017), the teaching strategy was Lectures, group discussion, demonstration role play and videos. As it was difficult to take the whole number of nurses, they were divided in two groups the theoretical part was six hours. The demonstration role play was used in the practical station for 12 hours in which application of care \& prevention steps was applied, a total of 50 staff nurses were trained.

Post Intervention Monitoring: Monitoring and supervision were carried out monthly for 3 months after the intervention to assess application of program by the same data collector.

Ethical consideration: The study proposal was submitted to a relevant Research and Ethics Committee for ethical approval. Letter was sent to respective nursing offices and hospital principals to inform them about the aim, design and importance of the study. Each Participant was well informed about the aim and potential benefits of the study, their verbal consent was taken and confidentiality was ensured. The permission of responsible authorities in hospital was secure. 
Results

Table 1 shows that the $(46 \%)$ of Staff nurses who were working in gynecology department their experience was from one to two years.

Table 1: Distribution of study population according to their experiences (n 50).

\begin{tabular}{|c|c|c|}
\hline Experiences & Frequency & Percentage \\
\hline 1-2 years & 23 & $46 \%$ \\
\hline 3- 5 years & 15 & $30 \%$ \\
\hline More than 5 years & 12 & $24 \%$ \\
\hline Total & 50 & $100 \%$ \\
\hline
\end{tabular}

Table 2: Distribution of study population according to training courses in cervical cancer prevention (n 50).

\begin{tabular}{|c|c|c|}
\hline Items & Frequency & Percentage \\
\hline Trained nurses & 2 & $4 \%$ \\
\hline Untrained nurses & 48 & $96 \%$ \\
\hline Total & 50 & $100 \%$ \\
\hline
\end{tabular}

Presents that most of staff nurses (96\%) they were not attended training courses in cervical cancer prevention.

Table 3: Distribution of staffnurses according to their knowledge regarding risk factors of cervical cancer (n 50).

$*$ P-value $=0.00$ Pearson Chi-Square $=15.9$.

\begin{tabular}{|c|c|c|c|c|}
\hline \multirow{2}{*}{ Items } & \multicolumn{2}{|c|}{ Pre } & \multicolumn{2}{c|}{ Post } \\
\cline { 2 - 5 } & No & \% & No & \% \\
\hline know & 29 & $58 \%$ & 41 & $82 \%$ \\
\hline Don't know & 21 & $42 \%$ & 9 & $18 \%$ \\
\hline Total & 50 & $100 \%$ & 50 & $100 \%$ \\
\hline
\end{tabular}

Table 3 presents that the staff nurses Knowledge about risk factors of cervical cancer before the teaching program about $(58 \%)$ of them knew the risk factors of cervical cancer,while $(42 \%)$ they didn't know, however after the teaching program there was an improvement in the knowledge of staff nurses regarding factors of cervical cancer,about ( $82 \%$ ) of the them knew, while (18\%)they did not know, a significant difference was found in knowledge of staff nurses between the pretest and posttest structured teaching program $(\mathrm{P}$-value $=0.00)$.

Table 4: Distribution of staff nurses according to their knowledge regarding Pap smear test definition and cervical screening methods (n 50). P-value $=0.00$ Pearson Chi-Square $=28.0$.

\begin{tabular}{|c|c|c|c|c|}
\hline \multirow{2}{*}{ Items } & \multicolumn{2}{|c|}{ Pre } & \multicolumn{2}{c|}{ Post } \\
\cline { 2 - 5 } & No & \% & No & \% \\
\hline know & 23 & $46 \%$ & 47 & $94 \%$ \\
\hline Don't know & 27 & $54 \%$ & 3 & $6 \%$ \\
\hline Total & 50 & $100 \%$ & 50 & $100 \%$ \\
\hline
\end{tabular}

Table 4 displays that the staff nurses knowledge about Pap smear test definition and cervical screening methods, before the teaching program, about (46\%) of them knew Pap smear test and cervical screening perfectly, while (54\%) they didn't know, however after the teaching program there was betterment in knowledge of staff nurses regarding Pap smear test definition and cervical screening methods, about $(94 \%)$ of the them knew, while $(6 \%)$ they did not know, there was statically significant difference between pre and post assessment $(\mathrm{P}$-value $=0.00)$.

Table 5: Distribution of staff nurses according to their knowledge regarding role of nurse in prevention of cervical cancer by health education.

\begin{tabular}{|c|c|c|c|c|}
\hline \multirow{2}{*}{ Items } & \multicolumn{2}{|c|}{ Pre } & \multicolumn{2}{c|}{ Post } \\
\cline { 2 - 5 } & No & \% & No & \% \\
\hline know & 22 & $44 \%$ & 44 & $88 \%$ \\
\hline Don't know & 28 & $56 \%$ & 6 & $12 \%$ \\
\hline Total & 50 & $100 \%$ & 50 & $100 \%$ \\
\hline
\end{tabular}

Table 5 shows that the staff nurses knowledge regarding role of nurse in prevention of cervical cancer by health education before teaching program (44\%) of them knew the correct option, while $(56 \%)$ they didn't know, after application of the teaching program there was an updating in their knowledge regarding role of nurse in prevention of cervical cancer by health education about (88\%) of them knew, while (12\%) they did not know.

\begin{tabular}{|c|c|c|c|c|}
\hline \multirow{2}{*}{ Items } & \multicolumn{2}{|c|}{ Pre } & \multicolumn{2}{c|}{ Post } \\
\cline { 2 - 5 } & No & \% & No & \% \\
\hline know & 10 & $20 \%$ & 50 & $100 \%$ \\
\hline Don't know & 40 & $80 \%$ & 0 & $0 \%$ \\
\hline Total & 50 & $100 \%$ & 50 & $100 \%$ \\
\hline
\end{tabular}

Table 6: Distribution of staff nurses according to their knowledge regarding Human papilloma virus (HPV) vaccine.

Table 6 presents that the staff nurses knowledge regarding Human papilloma virus (HPV) vaccine $(20 \%)$ gave the correct answer before they were attending teaching program and after the program their knowledge is improving (100\%) gave the typical answer.

Table 7: Distribution of staff nurses according to their knowledge regarding screening tests rather than Pap smear for cervical cancer.

P-value $=0.001$ Pearson Chi-Square $=15.00$.

\begin{tabular}{|c|c|c|c|c|}
\hline \multirow{2}{*}{ Items } & \multicolumn{2}{|c|}{ Pre } & \multicolumn{2}{c|}{ Post } \\
\cline { 2 - 5 } & No & $\%$ & & No \\
\hline know & 2 & $4 \%$ & know & 2 \\
\hline Don't know & 48 & $96 \%$ & Don't know & 48 \\
\hline Total & 50 & $100 \%$ & total & 50 \\
\hline
\end{tabular}

Table 7 presents that the staff nurses, knowledge regarding screening tests rather than Pap smear for cervical cancer, there was improvement in level of knowledge before teaching program (4\%) realized the correct answer while after program (76\%) realized answer perfectly.

In practical skills table 8 shows significant differences $(\mathrm{P}<0.000)$ between pre and post structured teaching program, Most of staff nurses $(80 \%)$ after program proceeded correct practices related to preparation and assisted in Pap smear procedure while before the Volume 2 | Issue 2 | 3 of 5 
program (54\%) proceeded the procedure correctly.

Table 8: Comparison of the study sample according to their practice skills regarding preparation and assisted in Pap smear procedure.

P-value $=0.00$.

\begin{tabular}{|c|c|c|c|c|}
\hline Items & \multicolumn{2}{|c|}{ Pre test } & \multicolumn{2}{c|}{ Post test } \\
\hline $\begin{array}{c}\text { Greet woman and explain the } \\
\text { procedure }\end{array}$ & $\begin{array}{c}50 \\
(100 \%)\end{array}$ & $0(0 \%)$ & $\begin{array}{c}50 \\
(100 \%)\end{array}$ & $0(0 \%)$ \\
\hline $\begin{array}{c}\text { Explain to woman that ideal time for } \\
\text { taken Pap smear is mid-cycle. }\end{array}$ & $\begin{array}{c}12 \\
(24 \%)\end{array}$ & $\begin{array}{c}38 \\
(76 \%)\end{array}$ & $\begin{array}{c}44 \\
(88 \%)\end{array}$ & $\begin{array}{c}6 \\
(12 \%)\end{array}$ \\
\hline $\begin{array}{c}\text { Explain to woman that the use of } \\
\text { vaginal cream or douche for 48hours } \\
\text { before test. }\end{array}$ & $0(0 \%)$ & $\begin{array}{c}50 \\
(100 \%)\end{array}$ & $2(4 \%)$ & $\begin{array}{c}48 \\
(96 \%)\end{array}$ \\
\hline $\begin{array}{c}\text { Explain to woman that had not } \\
\text { intercourse or douche with in the } 24 \\
\text { hours preceding the test. }\end{array}$ & $2(4 \%)$ & $\begin{array}{c}48 \\
(96 \%)\end{array}$ & $4(8 \%)$ & $\begin{array}{c}46 \\
(92 \%)\end{array}$ \\
\hline $\begin{array}{c}\text { Prepare special equipments needed } \\
\text { for the procedure (vaginal speculum, } \\
\text { spatula or cyto brush and glass slide }\end{array}$ & $\begin{array}{c}42 \\
(84 \%)\end{array}$ & $\begin{array}{c}8 \\
(16 \%)\end{array}$ & $\begin{array}{c}50 \\
(100 \%)\end{array}$ & $\begin{array}{c}0 \\
(0 \%)\end{array}$ \\
\hline $\begin{array}{c}\text { Provide privacy for women and } \\
\text { reassure her that the test is painless. }\end{array}$ & $\begin{array}{c}42 \\
(84 \%)\end{array}$ & $\begin{array}{c}8 \\
(16 \%)\end{array}$ & $\begin{array}{c}46 \\
(92 \%)\end{array}$ & $\begin{array}{c}4 \\
(8 \%)\end{array}$ \\
\hline $\begin{array}{c}\text { Instruct woman to empty her bladder. } \\
(96 \%)\end{array}$ & $2(4 \%)$ & $\begin{array}{c}48 \\
(96 \%)\end{array}$ & $2(4 \%)$ \\
\hline $\begin{array}{c}\text { Put woman in spine position and flexed } \\
\text { her knees and put her feet in stirrups to } \\
\text { exposed the site for examination }\end{array}$ & $\begin{array}{c}46 \\
(92 \%)\end{array}$ & $4(8 \%)$ & $\begin{array}{c}50 \\
(100 \%)\end{array}$ & $0(0 \%)$ \\
\hline $\begin{array}{c}\text { Ask the woman to take deep breathes } \\
\text { and try to relax during insertion of } \\
\text { speculum }\end{array}$ & $\begin{array}{c}6 \\
(12 \%)\end{array}$ & $\begin{array}{c}44 \\
(88 \%)\end{array}$ & $\begin{array}{c}22 \\
(44 \%)\end{array}$ & $\begin{array}{c}27 \\
(54 \%)\end{array}$ \\
\hline $\begin{array}{c}\text { Explain to woman that may experience } \\
\text { small amount of spotting after test. }\end{array}$ & $\begin{array}{c}6 \\
(12 \%)\end{array}$ & $\begin{array}{c}44 \\
(88 \%)\end{array}$ & $\begin{array}{c}22 \\
(44 \%)\end{array}$ & $\begin{array}{c}27 \\
(54 \%)\end{array}$ \\
\hline $\begin{array}{c}\text { Be sure that finding were noting during } \\
\text { request form (during visualization of } \\
\text { the cervix observe clear excess mucus } \\
\text { discharge-abnormal area in the cervix) }\end{array}$ & $\begin{array}{c}26 \\
(52 \%)\end{array}$ & $\begin{array}{c}24 \\
(48 \%)\end{array}$ & $\begin{array}{c}32 \\
(64 \%)\end{array}$ & $\begin{array}{c}18 \% \\
(36 \%)\end{array}$ \\
\hline $\begin{array}{c}\text { Labeled the smear and sent it to the lab } \\
(88 \%)\end{array}$ & $\begin{array}{c}47 \%) \\
(46 \%)\end{array}$ & $\begin{array}{c}48 \%) \\
(80 \%)\end{array}$ & $\begin{array}{c}10 \\
(20 \%)\end{array}$ \\
\hline
\end{tabular}

Table 9 presents that (54\%) of staff nurse's implemented counseling in system to be followed in doing Pap smear correctly, but after program most of them (90\%) implemented it in right way.

Table 9: Comparison of the study sample according to their practice regarding counseling \&health education in system to be followed in doing Pap smear.

\begin{tabular}{|c|c|c|c|c|}
\hline \multirow{2}{*}{ Items } & \multicolumn{2}{|c|}{ Pre test } & \multicolumn{2}{c|}{ Post test } \\
\cline { 2 - 5 } & done & $\begin{array}{c}\text { not } \\
\text { done }\end{array}$ & done & $\begin{array}{c}\text { not } \\
\text { done }\end{array}$ \\
\hline $\begin{array}{c}\text { Ggive women counseling and health } \\
\text { education regarding system to be followed } \\
\text { in doing Pap smear according women ages }\end{array}$ & $\begin{array}{c}27 \\
(54 \%)\end{array}$ & $\begin{array}{c}23 \\
(36 \%)\end{array}$ & $\begin{array}{c}45 \\
(90 \%)\end{array}$ & $\begin{array}{c}5 \\
(10 \%)\end{array}$ \\
\hline
\end{tabular}

\section{Discussion}

Knowledge is an essential first step in the development of behavior there a study conducted at in the gynecology department to evaluate the effectiveness of structured teaching program on knowledge and practice of staff nurses regarding prevention of cervical cancer. The data collected by the researcher and trained date collector through questionnaires (50) and check list filled from staff nurses, who they completed the teaching program. More than third (46\%) of staff nurses their experience was from one to two years and most of them $(96 \%)$ they were not attended training courses in cervical cancer prevention and this shortage of training courses in cervical cancer prevention motive staff nurses to seek more knowledge and best practice to improve their performance so their participation in the study was perfect. The finding of study related to staff nurses knowledge showed that staff nurses before the teaching program had poor knowledge regarding the risk factors of cervical cancer the program increased their knowledge from $(58 \%)$ at pretest to $(82 \%)$ in post test, indicating significant differences $(p=0.000)$ in their knowledge between pretest and posttest period, compared to previous study in India the study was conducted as a descriptive cross sectional survey, among nursing staff of a tertiary care teaching and referral institute of rural India to assess the nursing staff knowledge, attitude and practices about cervical cancer screening a higher percentage of participants (58\% versus. $36 \%$ in pre-test) in our study knew risk factors for development of cancer cervix [9].

Concerning the Knowledge of staff nurse regarding Pap smear test definition and cervical screening methods, there was clearly an improvement in the knowledge of staff nurses, before the teaching program $(46 \%)$ of the staff nurses knew it rightly, as for after the teaching program most of them (94\%) knew the Pap smear test definition and cervical screening methods completely, indicating significant differences $(\mathrm{P}=0.00)$ in their knowledge between pretest and posttest period, this was corresponded with the findings of previous study conducted in India to assess the effectiveness of structured education on knowledge regarding prevention of cervical cancer among auxiliary nursing midwifery (ANM) students the findings showed that ANM student had deficit knowledge regarding prevention of cervical cancer, the total pretest mean score secured by ANM student nurses are 13.45 on a scale of 1-30. The total posttest mean score secured by ANM student nurses are 28.92 on a scale of 1-30 [10].

In our study the main reason for this lack of depth on knowledge of cervical cancer prevention among staff nurses in pre test assessment is their training curriculum. Moreover, cervical cancer prevention issue has largely been perceived as the concern of physicians. Despite existence of national guidelines for cervical cancer screening for many years ago, their effective implementation is yet to be seen.

A significant differences appeared $(\mathrm{P}<0.05)$ in practical skills of staff nurses between pre and post structured teaching program, Most of them (80\%) after program performed correct practices related to preparation and assisted in Pap smear procedure while before the program $(54 \%)$ performed the procedure correctly $(\mathrm{P}$-value $=$ $0.00),(54 \%)$ of staff nurses demonstrated counseling in system to be followed in doing Pap smear correctly, but after program 
most of them $(90 \%)$ demonstrated it in right way, this is similar to pervious study done by Shashank Shekhar et al in India, mainly during pre test assessment, pervious study revealed that nearly $60 \%$ of participants were routinely managing female patients however only $24 \%$ of them were doing vaginal examinations frequently and only few $(8 \%)$ were using speculum while doing vaginal examination. Most of participants $(85 \%)$ had never taken a pap smear, 70\% never asked patients about their cervical cancer screen status, and $90 \%$ of the respondents had never referred patients for screening of cervical cancer [9].

The current study reinforces the finding that there is a need for incorporation of more content of prevention of cervical cancer and role of nurse in prevention in syllabus of faculties and institution of nursing, training program and need for the structured education among staff nurses after graduation .Thus the finding suggests that the staff nurses do not have $100 \%$ knowledge regarding prevention of cervical cancer. It is a very important aspect because without knowledge \&practice on prevention of cervical cancer nurses cannot practice for their actually responsibilities of women health.

\section{Conclusion}

The study proved that structured teaching program among staff nurses was effective and efficient; there was significant statistical betterment in knowledge and practice skills after the teaching program offered to the participants $(\mathrm{P}<0.05)$.

\section{Recommendation}

The study recommended that:

- $\quad$ Staff nurses may worked in district places should emphasis on the subject matter related to legal prevention of cervical cancer as it is major health problem in Sudan \& it is today's need.

- The diploma and BSc curriculums need to be upgraded as much as possible to cover many aspects of cervical cancer $\&$ its prevention.

- Regular in-service/ workshops,conferences, educational materials related to prevention of cervical cancer \& advance treatment modalities should be provided to the staff nurse.

\section{References}

1. International Agency for Research on cancer word health organization. Word cancer day. 2017.

2. Radiation and isotope center in Khartoum RICK and the national cancer institute of university of Gezira NCI-UG in Wadmedani, Gezira state institute of nuclear medicine, molecularbiology oncology. 2012.

3. Adia Ahmed fadlala. Cervical cancer in Sudan. Geneva Foundation for medical Education and research GFMER Sudan. 2012.

4. Hassan FM, Khir Elseed M. Cervical cancer screening among Sudanese women. GJO. 2009; 6.

5. Amercan College of obstetricians and gynecologists cervical cancer screening and prevention practice. Bulletin NO 157. Obstetricians and gynecologists. 2016; 127: e120.

6. Gravitt PE, Belin son JL,Salmeron J,et al. Looking ahead a case for human papilloma virus testing of self sampled vaginal specimens as a cervical cancer screening strategy. Int J cancer. 2011; 129: 517-527.

7. Rogers NM. Nurses role in the prevention of cervical cancer among underserved and minority population $\mathrm{J}$ community health. 2009.

8. Turkistanli EC. Asian J cancer prev. cervical cancer prevention and early detection the role of nurses and midwives.

9. Shekhar S, Sharma C, Thakur S, et al. Cervical Cancer Screening Knowledge Attitude and Practices among Nursing Staff in a Tertiary Level Teaching Institution of Rural India. Asian Pacific Journal of Cancer Prevention. 2013; 14: 36413645.

10. Nootan R. Mali, Ramling. Effect of Structured Education on Knowledge Regarding Prevention of Cervical Cancer among ANM. Students Mali2International Journal of Science and Research IJSR ISSN Online 2319-7064.

(C) 2018 Amal Mohammed Hamid \& Ahmed Mohammed Ahmed Fadalla. This article is distributed under the terms of the Creative Commons Attribution 4.0 International License 